\title{
Research
}

\section{Enhancing Adaptive Capacity in Food Systems: Learning at Farmers' Markets in Sweden}

\author{
Rebecka Milestad $^{1,2}{ }^{\text {, Lotten Westberg }}{ }^{1}$, Ulrika Geber ${ }^{3}$, and Johanna Björklund ${ }^{4}$
}

\begin{abstract}
This article examines how local food systems in the form of farmers' markets can enhance adaptive capacity and build social-ecological resilience. It does this by exploring the learning potential among farmers and customers. Learning can enable actors to adapt successfully and thus build adaptive capacity. Three forms of learning are investigated: instrumental, communicative, and emancipatory. These forms of learning constitute the foundation for lasting changes of behaviors. Local food systems are characterized by close links and opportunities for face-to-face interactions between consumers and producers of food, and are also institutions where farmers and customers can express and act upon their ethical values concerning food. However, local food systems are still a marginal phenomenon and cannot be accessed by all consumers. Interviews were held with customers and farmers, and the interactions between farmers and customers were observed at two farmers' markets in Sweden. Customers and farmers were found to learn and adapt to each other due to the opportunities offered by the farmers' markets. We found that farmers and customers learned in the instrumental and communicative domains, but could not confirm emancipatory learning. We concluded that the feedback between customers and farmers offers the potential for learning, which in turn contributes to adaptive capacity. This can be a driving force for building resilience in the food system.
\end{abstract}

Key Words: adaptive capacity; learning; local food systems; farmers' markets; short food chains; socialecological resilience

\section{INTRODUCTION}

There is increasing experience of the physical and psychological displacement of both food production from processing and production from consumption (Sundkvist et al. 2005). The geographical and cognitive distance between food producers and consumers has increased in the developed world since the 20th century because fewer people are directly involved in producing food, production chains are more complex, and fewer people know how to grow their own food or how food is produced (Hendrickson and Heffernan 2002, Eden et al. 2008). These changes have been accompanied by loss of agricultural resilience and diversity, degradation of the environment, dislocation of community, and loss of identity and place (Pretty 1998, Feagan 2007).

The concept of local food systems attempts to link food and place for consumers and producers
(Connell et al. 2008). Farmers' markets are an expression of local food systems, and as such they are sites for commercial exchanges and negotiated meaning in the local food landscape (Smithers et al. 2008). Localness, naturalness, personal trust, a sense of community, reciprocity, and social connection are key modes associated with assessing the worth of farmers' markets (Hinrichs 2000, Holloway and Kneafsey 2000).

The opportunity for direct personal communication among participants in local food systems is important for the development of such systems (Hinrichs 2000, Jarosz 2000), which can be perceived as potential learning situations in which the participants exchange experiences and information about the activities that make up the food system. Building the capacity of individuals, organizations, and societies to learn through change is fundamental in natural resource management, including farming and the food system (cf. Armitage 
et al. 2008, Darnhofer et al. 2010). Learning is an important precondition for building resilience (Berkes et al. 2003, Armitage et al. 2008) by enhancing the adaptability of the actors involved (Walker et al. 2004). This is because learning can enable actors to respond accurately to socialecological feedback (Carpenter et al. 2001, Folke et al. 2003, Armitage et al. 2008). Although learning is an important concept in the literature on resilience and local food systems, few authors have described the actual learning that takes place and what it implies for sustainable development (cf. Hinrichs et al. 2004, Armitage et al. 2008, Svenfelt and Carlsson-Kanyama 2010). Svenfelt and CarlssonKanyama (2010) call for research on the potential for bringing food production systems closer to urban consumers, thus establishing a link between food consumption and the ecology of food production. Knowledge and learning can be this link. This paper contributes to the understanding of learning by exploring and defining the learning potential of farmers' markets in more detail.

The overall question that guided our research was whether local food systems provide learning situations, and if so, what the actors learn. If they learn about the food system, this can strengthen their adaptive capacity, in turn supporting resilience and more sustainable development of the food system. We defined learning as "...the process of using a prior interpretation to construe a new or a revised interpretation of the meaning of one's experience in order to guide further action" (Mezirow 1991:12). In this definition, action is not only seen as visible behavior, but includes making a decision, solving a problem, modifying an attitude, etc. (Mezirow 1991). Learning is explored here through examining the quality of the face-to-face interactions taking place between actors in local food systems. In line with the definition, if the actors taking part in farmers' markets are able to learn, they may revise prior interpretations (or make new ones) on, for example, their roles or the meaning of the food system as a whole, and use them to modify their attitudes, remake decisions, and/or adapt their behavior when dealing with issues relating to the food system.

\section{Resilience, adaptive capacity, and learning}

Resilience and adaptive capacity appear to be useful concepts when analyzing food systems. A food system is complex and dynamic, and it exhibits interdependence between humans and ecosystems (Darnhofer et al. 2010). Resilience is the capacity of a system to absorb disturbance: to undergo change and still retain essentially the same function and structure (Carpenter et al. 2001). Adaptive capacity is the ability of actors to cope with change and dynamics (Gunderson and Holling 2002). Partly depending on the adaptive capacity of the actors in the system (farmers, processors, retailers, consumers), resilience can be built or eroded. Thus, a high adaptive capacity of food system actors is a prerequisite for their resilience-building capacity (Walker et al. 2004, Fazey et al. 2007), which is vital in the current context of climate change, changes in politics, and market fluctuations. A social-ecological system, such as a food system, with low adaptive capacity is more vulnerable to shocks, disturbances, and sudden changes (Adger 2006). Learning is a significant factor when building adaptive capacity and social-ecological resilience (Berkes and Folke 1998, Berkes et al. 2003, Gunderson et al. 2006, Fazey et al. 2007). Thus, if actors learn, there is a high probability that they will increase their adaptive capacity. The social context of a farmers' market is a mediating institution that can provide an arena for learning (Hinrichs et al. 2004). In other words, the feedback possible in faceto-face interactions at farmers' markets can enable learning, which may enhance the adaptive capacity of the participants and in turn build socialecological resilience into the food system. In addition, enhancing adaptive capacity for socialecological resilience can involve bridging between different scales of management (Olsson et al. 2007), enhancing diversity (cf. Elmqvist et al. 2003), and building social networks and trust (Walker et al. 2006).

Face-to-face interactions between producers and consumers are possible at the scale of local food systems and are an opportunity for learning. When farmers and customers meet face-to-face, they have the possibility to learn from and about each other, which in turn can improve their adaptive capacity. Hinrichs et al. (2004) investigated social learning in relation to innovations at farmers' markets and found that attending and selling at the farmers' market more often increased the opportunities for learning. Furthermore, farmers' markets enabled producers and consumers to take back some responsibility for evaluating the quality of the produce traded (Kirwan 2006). Interactions between producers and consumers also made the environmental and ethical performance of 
businesses more visible and thereby helped to improve both (Hinrichs et al. 2004). For example, farmers have been found to indicate a willingness to reduce chemical inputs to meet consumer demands (Hunt 2007). The farms supplying the farmers' markets investigated in this study have high on-farm biodiversity as a result of selling locally (Björklund et al. 2009).

\section{Local food systems}

Farmers' markets are part of the movement to restore local food systems. Local food networks are defined by shorter distances between producers and consumers; relatively small farm size and organic or low external input production methods; the existence of food purchasing venues such as farmers' markets; and a commitment to sustainable food production, distribution, and consumption (Jarosz 2008). The notion of distance is particularly important to local food systems (Allen et al. 2003, Sundkvist et al. 2005). Greater distance means that more resources are required to produce a calorie of food; that there is no direct relationship between producer and consumer; and that the responsibility for production is separated from consumption (Connell et al. 2008). It has been argued that local food systems have the capacity to re-establish positive relationships between producers and consumers and to generate social, economic, and environmental benefits (cf. Smithers et al. 2008). For farmers, they provide scope for improved economic viability and the ability to contribute more directly to the local community (Marsden et al. 2000). For customers, they provide scope for increasing their knowledge about the origins of food and access to fresher food (Sage 2003, Lamine 2005). The economic benefits lie in the potential to retain a greater proportion of the money spent on food in the local economy, and the environmental advantages are associated with less ecologically depleting farming systems (Smithers et al. 2008). Local food system advocates argue that eliminating market intermediaries improves the outcome for small-scale farmers and low-income consumers compared with the conventional food market (Guthman et al. 2006). Thus, many scholars have embraced local agro-food initiatives as a solution to the problems of global industrial agriculture (cf. DuPuis and Goodman 2005), presenting them as an alternative to the mainstream food system and an alternative vision of social-ecological relations embedded in food (DeLind 2002, Allen et al. 2003).
The change of scale is decisive. Because things are perceived as not going well on a large scale, a change of scale may be required (Lamine 2005).

However, it is important not to conflate the scale of the food system with any specific characteristics of that food system (Hinrichs 2003, Born and Purcell 2006). The argument in favor of increasingly local food chains assumes and reinforces an association between localness, taste, naturalness, safety, nutritional value, environmental quality, and the local economy that may not exist (Edwards-Jones et al. 2008). Having local food systems is not an end in itself, but rather a means to an end, such as socialecological resilience or social justice (cf. Born and Purcell 2006). Allen (2004) points out that working at the local level is important, but insufficient to develop environmentally sound and socially just agro-food systems. In order to pursue collective goals - environmental sustainability and social justice - farmers and consumers must actively weave together individual economic and collective political goals (Alkon 2008). Without a program to promote the availability and knowledge of healthy food for the general public, there is a good chance that food quality will be stratified, with the relatively well-off having the best access and the rest of society being left with food created primarily for mass production and easy distribution, product quality being a secondary concern (Guthman 2008, Macias 2008).

\section{Farmers and consumers at farmers' markets}

Research on farmers who sell at farmers' markets has revealed that they are attracted to the economic and social benefits involved. Socializing with other farmers and customers is also valuable to the farmers, as is the positive feedback given by customers at the market (Griffin and Frongillo 2003). Producers value the social interaction at farmers' markets for its own sake (Kirwan 2006). In a review of research on farmers' markets in the United States, Brown (2002) concluded that farmers use farmers' markets because they feel that this is the best market channel available to them, with the farms concerned more likely to be small in scale.

The reasons why customers shop at farmers' markets can be summarized as a combination of highquality, fresh, and locally produced products and a sociable and interactive atmosphere where the consumer knows the producer (Brown 2002, 
Kirwan 2006, Moore 2006, Connell et al. 2008). At the market, customers are more likely to engage in social encounters than supermarket customers (LaTrobe 2001). The opportunities at farmers' markets to build a relationship with producers enables customers to feel more confident in the quality of products - mainly by being able to assess the integrity of the producers themselves and thereby their trustworthiness (Kirwan 2006). A common stereotype is that the farmers' market customer is more inquisitive about the manner in which food is produced (Smithers et al. 2008). However, Asebø et al. (2007) found that producers at Norwegian farmers' markets felt it was important to communicate how and where food was produced, whereas customers were less concerned about this aspect.

Consumers normally have a multidimensional concept of quality, which goes beyond chemical and physical variables and may include a wide range of social factors relating to the traditions and experiences of people in the food chain (Parrott et al. 2002, as cited in Edwards-Jones et al. 2008). People who shop more often at farmers' markets can have conceptions of "good food" that are different from those of people who shop for food elsewhere (Connell et al. 2008). Furthermore, people who shop at farmers' markets more often take more factors into account when purchasing food. Thus, a farmers' market can be seen not only as a place to buy "good food," but also as a medium for expressing values associated with food choices (Connell et al., 2008).

The ability to afford the produce is a determining factor for customer visits to a farmers' market (Guthman et al. 2006). Many farmers' markets are located in high-end areas because the farmers can make more money there (cf. Guthman 2008). Indeed, customers at farmers' markets have a higher level of education and a higher income than the average citizen (Hunt 2007). The presence of people with "alternative" lifestyles might also be associated with a concentration of local food businesses (Ilbery et al. 2006). As we shall see, the farmers' markets described in this study were no different.

\section{METHODOLOGY}

The field study was undertaken during 2005 and 2006 at two farmers' markets in Sweden. The results are based on interviews with five farmers (or farming couples) and nine customers, and on observations of interactions between farmers and customers during market days.

\section{Sampling}

The two markets studied were the Farmers' Own Market $^{\mathrm{TM}}$ in Stockholm and Örebro. The Farmers' Own Market is an economic association for farmers selling their own products at markets in 16 towns (at present) in Sweden. Only products that farmers have grown or reared themselves on farms within a $250-\mathrm{km}$ radius of the market can be sold. The Stockholm farmers' market is located in an "alternative" area (cf. Ilbery et al. 2006), whereas the Örebro market is located in a mixed area. Neither of the markets is located so as to attract the attention of the minority/low-income populations of the cities, and there is no outspoken intention to attract this group of consumers.

Sample farms supplying these markets were selected by convenience (Bryman 2004) through contact with advisors working with local distribution networks. We carried out in-depth studies of five farms (Table 1): two specialize in horticulture (F1 and F2); two mainly rear animals in the form of sheep (F3) or beef cattle (F4); and one mainly produces cereals and sells mill products, but also has beef cattle (F5). The farmers sell at the Farmers' Own Market in Stockholm, Örebro, or both. In addition, the farmers sell at the farm gate, to restaurants, and to grocery stores. Farms F3 and F5 also sell meat and cereals through mainstream channels. The main factors characterizing the farms in the study, in comparison with the average Swedish farm, were that they are organic and workintensive, have a low monetary turnover, and generally use few purchased inputs. The estimated income for the farms was around 20,000 USD or lower per person per year. This is quite low, especially considering that this was the sole income for all farms except two (Table 1).

Customers were randomly approached at the two markets on different occasions as they were purchasing goods from one of the farmers in the study. Most were middle-aged, female, and frequent visitors to the market (Table 2). The customers generally had higher or professional education, but only one (C7) could be described as a typical highincome consumer (although consumers were not questioned directly about their income). Despite this, weekly spending at the market was a couple of 
Table 1. Descriptions of the farms in the study.

\begin{tabular}{|c|c|c|c|c|c|}
\hline & $\mathrm{F} 1$ & $\mathrm{~F} 2$ & F3 & $\mathrm{F} 4$ & F5 \\
\hline County & Örebro & Stockholm & Örebro & Örebro & Örebro \\
\hline Main product & $\begin{array}{l}\text { Vegetables, } \\
\text { potatoes }\end{array}$ & Vegetables & Lamb, sausages & Beef & $\begin{array}{l}\text { Cereals, flour, hard } \\
\text { bread, beef }\end{array}$ \\
\hline Production system & Organic & Organic & Organic & Organic & Organic \\
\hline Arable land & 24 ha & $3.5 \mathrm{ha}$ & 100 ha & 47 ha & 130 ha \\
\hline Animals & $\begin{array}{l}\text { Leased grazing for } \\
\text { beef cattle }\end{array}$ & - & 550 ewes & 35 cows & $\begin{array}{l}11 \text { beef cows, } 20 \\
\text { ewes }\end{array}$ \\
\hline Other activities & Trainees & Trainees & $\begin{array}{l}\text { Cattle dogs, dog } \\
\text { training courses }\end{array}$ & Full-time teacher & $\begin{array}{l}\text { Forest, small } \\
\text { conference facility, } \\
\text { hydro-electric plant }\end{array}$ \\
\hline $\begin{array}{l}\text { Marketing of } \\
\text { products }\end{array}$ & $\begin{array}{l}\text { Farmers' market, } \\
\text { farm gate, local } \\
\text { grocery stores, } \\
\text { restaurants }\end{array}$ & $\begin{array}{l}\text { Farmers' market, } \\
\text { farmer } \\
\text { cooperation, farm } \\
\text { gate, box scheme }\end{array}$ & $\begin{array}{l}\text { Farmers' market, } \\
\text { local stores, } \\
\text { national butcheries }\end{array}$ & $\begin{array}{l}\text { Farmers' market, } \\
\text { local grocery } \\
\text { stores, Internet }\end{array}$ & $\begin{array}{l}\text { Farmers' market, } \\
\text { local and distant } \\
\text { grocery stores, mill }\end{array}$ \\
\hline $\begin{array}{l}\text { Proportion of } \\
\text { produce sold } \\
\text { locally measured } \\
\text { by income }\end{array}$ & $100 \%$ & $100 \%$ & $40 \%$ & $100 \%$ & $90 \%$ \\
\hline
\end{tabular}

hundred SEK (1 USD = 7.25 SEK) in all recorded cases (Table 2). The predominance of customers from the Örebro market is due to three interviews with Stockholm customers being lost due to technical problems.

\section{Interviews and observations}

Using a thematic interview guide, semi-structured interviews (Bryman 2004) were carried out with each farmer or farming couple on two occasions over two years. The interviews focused on how products were processed and sold, the reason for selling locally, and farmers' perceptions of their interactions with customers. In addition, agronomic and economic data from 2004 and 2005 were collected.

On five occasions in 2005 (three in Stockholm and two in Örebro) and three occasions in 2006 (one in Stockholm and two in Örebro), dialogues between the farmers and their customers were observed during market days (cf. Bryman 2004). Notes were made of conversations and other kinds of interactions and activities that took place. In total, 153 observations were recorded.

The nine sample customers were interviewed by telephone using a structured interview guide aimed at obtaining information about their consumption patterns, values, and preferences regarding food and their perception of the opportunities to meet and converse with food producers.

The interviews with farmers and customers were recorded, transcribed, and analyzed thematically through iterative reading of the interview material, categorization of the material by themes, and quantification of statements (Miles and Huberman 1994, Kvale 1996). The documented observations from market occasions were used for method triangulation (Kvale 1996), enabling a critical perspective of descriptions given by farmers and customers. 
Table 2. Descriptions of the customers interviewed in the study.

\begin{tabular}{|c|c|c|c|c|c|c|c|}
\hline Consumer & Age & Gender & City & Profession & $\begin{array}{l}\text { No. of people } \\
\text { in household }\end{array}$ & $\begin{array}{l}\text { Frequency at } \\
\text { farmers' }^{\prime} \text { market }^{\dagger}\end{array}$ & $\begin{array}{l}\text { Weekly } \\
\text { spending at the } \\
\text { market (SEK) }\end{array}$ \\
\hline $\mathrm{C} 1$ & $50 \mathrm{~s}$ & Female & Örebro & Dental nurse & 2 & Several times & nd \\
\hline $\mathrm{C} 2$ & 44 & Male & Örebro & nd & 4 & Several times & nd \\
\hline $\mathrm{C} 3$ & 63 & Female & Örebro & Social worker & 1 & $\begin{array}{l}\text { Almost every } \\
\text { week }\end{array}$ & $200-300$ \\
\hline $\mathrm{C} 4$ & 55 & Male & Stockholm & Carpenter & 2 & Every week & $500-600$ \\
\hline $\mathrm{C} 5$ & 60 & Female & Stockholm & Art director & 2 & Several times & $300-400$ \\
\hline C6 & 29 & Female & Örebro & Teacher & 2 & $\begin{array}{l}\text { Almost every } \\
\text { week }\end{array}$ & nd \\
\hline $\mathrm{C} 7$ & 55 & Female & Örebro & Hospital director & 4 & Every week & $400-500$ \\
\hline $\mathrm{C} 8$ & 56 & Female & Örebro & $\begin{array}{l}\text { University } \\
\text { administrator }\end{array}$ & 1 & $\begin{array}{l}\text { Almost every } \\
\text { week }\end{array}$ & nd \\
\hline C9 & $50 \mathrm{~s}$ & Male & Örebro & Antique restorer & 2 & $\begin{array}{l}\text { Almost every } \\
\text { week }\end{array}$ & $300-500$ \\
\hline
\end{tabular}

†n relation to the 11 weeks it is open during harvest season.

\section{Identification of learning possibilities}

In order to explore the question of whether face-toface communication in local food systems provides opportunities for learning and thereby strengthens the adaptive capacity of the actors involved, we first needed to clarify the concepts of "communication" and "learning." Human communication can be seen as symbolic action through which our beliefs, attitudes, and behaviors are mediated (Burke 1966). Based on an understanding of communication as symbolic action, Mezirow (1991) developed a theory of transformative learning that describes three domains in which learning can take place: instrumental learning, communicative learning, and emancipatory learning. Instrumental learning involves learning for control and manipulation of the environment, including other people. Within the context of the farmers' market, one result of instrumental learning could be a farmer learning which crops to grow or a customer learning which of the market stalls sells a certain tomato variety.
Reaching an understanding is the inherent purpose of human communication. Being able to take part in communication requires a universal core of basic attitudes that we share with those with whom we are communicating, a tacit consensus about norms and values, and fundamental rules that we must master in order to understand what people mean and to make ourselves understood. Learning within the communicative domain means understanding more about the perspectives and interests of others, what others mean, and how to communicate one's own meaning, to make sense of and relate to the particular context within which the communication takes place. Within the context of the farmers' market, communicative learning could occur when food actors develop knowledge about other actors' values and priorities, not in order to control them, but for the purpose of understanding and relating to each other and the context.

Emancipatory learning is learning about one's self, about developing the ability to consciously reflect 
upon one's competences, skills, and inabilities. The emancipation within this learning domain refers to emancipation from, for example, linguistic, epistemic, institutional, or environmental forces that we take for granted (Mezirow 1991). Within the context of the farmers' market, this could occur when actors are inspired to challenge their existing self-perceptions by trying to deal with difficulties or solve problems that they believed to be beyond their control. Emancipatory learning is a function of communicative learning, that is, how we are interpreted by others, but we also gain knowledge about ourselves through instrumental learning, by getting feedback on our skills and abilities to accomplish and perform.

Although the three learning dimensions are analytically distinguishable, in practice they are interrelated and interdependent. An act of speech may be instrumental, but it is always communicative as well (Forester 1993). When a person speaks, something more than the content of the words is always conveyed. The words spoken may confirm, encourage, promise, criticize, wonder, etc., conveying an intention or a meaning to those listening. Thus, communication is never simply a transmission of factual matters. The factual content in the act of speech is linked to norms or values interpreted by those listening and affected by the context within which the conversation takes place.

In this analysis, we looked for qualitative aspects of the observed communications that reflected the different learning domains, in order to determine and discuss whether farmers and customers used and benefited from the learning opportunities at the markets. When learning opportunities were found, we linked this to the potential for building the adaptive capacity of the farmers and customers in the study. However, we did not assess the actual actions and behaviors of farmers and customers here. In the case of the farmers, this has been done elsewhere (Björklund et al. 2009). Our contribution here involves detailing how learning (as a mechanism for resilience) can be analyzed in a resilience framework, rather than analyzing the actual outcomes for resilience as such.

\section{RESULTS AND ANALYSIS}

\section{Instrumental learning at the farmers' markets}

When customers and farmers in the study were asked what they talked about with each other during market occasions (Table 3) and what they thought they learned from each other, they referred to conversations in which they gained knowledge about factual matters that they regarded as useful (Table 4). This is learning within the instrumental domain, that is, learning for control and manipulation of the environment, including other people (Mezirow 1991).

The customers mainly mentioned that they took the opportunity to ask farmers about food items they were not familiar with; how to use and store the food they bought at the market; and about the taste, availability, and quality of different products (Table 4). Consequently, they could be seen as learning about new and for them unusual varieties, about when different vegetables were in season, how products tasted, and how to use different products. Some customers stated that they had learned how vegetables should look when they were really fresh. After attending the farmers' market and interacting with farmers and other customers, they had learned to be more exacting about food and to demand higher quality. Some customers also believed that visiting the farmers' market made them more interested in food and cooking in general. As one customer (C8) said:

\section{[I] think it's terribly sad having only these big [supermarkets]. I'd rather have this contact when I shop [...] up there [at the market]. One can talk to them and hear what this is and where it comes from and what it looks like and what I can do with it, because there's a lot you don't recognize. I think that's fun, especially these roots and tubers, I think that can be a bit tricky.}

According to the farmers surveyed, important conversations and learning were connected to information regarding customers' wishes, sense of taste, knowledge, and ability to use the products offered by the farmers (Table 4). This kind of information was useful for farmers because it increased their ability to judge and influence aspects connected to farming and selling at the market. 
Table 3. Things farmers and customers talked about at the farmers' market.

\begin{tabular}{|c|c|c|c|}
\hline Subject & $\begin{array}{l}\text { Farmers stating this } \\
(n=5)\end{array}$ & $\begin{array}{l}\text { Consumers stating this } \\
(n=9)\end{array}$ & $\begin{array}{l}\text { Number of observations } \\
(n=153)^{\dagger}\end{array}$ \\
\hline $\begin{array}{l}\text { How to use the products (recipes, } \\
\text { storage, try new) }\end{array}$ & $\mathrm{F} 1, \mathrm{~F} 2, \mathrm{~F} 3$ & $\mathrm{C} 1, \mathrm{C} 3, \mathrm{C} 8, \mathrm{C} 9$ & 32 \\
\hline $\begin{array}{l}\text { About the products (availability, } \\
\text { varieties, quality, taste) }\end{array}$ & $\mathrm{F} 1, \mathrm{~F} 2, \mathrm{~F} 3, \mathrm{~F} 4$ & $\mathrm{C} 3, \mathrm{C} 4, \mathrm{C} 6, \mathrm{C} 7$ & 50 \\
\hline Production methods of the farm & F1, F2, F3, F4, F5 & $\mathrm{C} 6$ & 23 \\
\hline Give feedback, confirm relation & F1, F2, F3, F4, F5 & $\mathrm{C} 3, \mathrm{C} 5$ & 45 \\
\hline Farm location & F3, F5 & - & 5 \\
\hline Market practicalities & F3 & - & 17 \\
\hline $\begin{array}{l}\text { Other (skin problems, how consumers } \\
\text { grow vegetables, not much talk at all) }\end{array}$ & F1, F5 & $\mathrm{C} 1, \mathrm{C} 2, \mathrm{C} 9$ & - \\
\hline
\end{tabular}

${ }^{\dagger}$ Some observations were attributed to more than one subject.

Generally, the farmers did not feel that most customers were very eager to ask profound questions. However, one farmer (F2) interpreted this not as disinterest, but as approval: If they shopped, they liked the produce and that was all that mattered. At the same time, all farmers stated that they talked about production methods occasionally with customers at the market (Table 3). This included conversations about animal breeding, transport, slaughter, pests in vegetables, and why certain varieties of potatoes were not available as organic produce. In many cases, the farmers offered information about the production methods to customers unasked. The farmers also volunteered information about crops and varieties they wanted the customers to try, and some tried to attract customers by talking about the high quality of their produce. One vegetable grower (F1) explained:

[I can teach them] all they can do with it [the produce] and that there are new things. There are people that don't know how to deal with things, and things they've seen in a shop but they don't dare to buy. Because they don't know what to do with it. Me, they dare ask. And then I have to have a good answer as well.
Our market day observations supported the statements of the interviewees (Tables 5 and 6). The customers learned about crops, varieties, tastes, availability, and how to store and prepare products from the market. In cases where the interaction between customers and farmers was not restricted to a purely commercial transaction, the conversation often started with farmers recommending something or customers pointing at products with questions about their names or how they tasted, or asking about how products they had bought should be stored or prepared. Conversations of this kind gave farmers the opportunity to learn about what customers wanted, liked and did not like, what they knew, and how they perceived the information offered by the farmers.

The observations showed that the opportunities for learning within the instrumental domain varied from farmer to farmer (Table 6). Some of the farmers tried to attract customers to their stalls by engaging in conversations with them and offering them samples of their products. For example, the sheep farmers (F3) offered mutton stew and distributed recipes. The cereal farmer (F5) offered samples of hard bread and tried to talk customers into slowing down 
Table 4. Things farmers and customers said they learned at the farmers' market.

\begin{tabular}{|c|c|c|c|}
\hline Farmers say they learn about & $\begin{array}{l}\text { Farmers stating } \\
\text { this }(n=5)\end{array}$ & Consumers say they learn about & $\begin{array}{l}\text { Consumers stating this } \\
(n=9)\end{array}$ \\
\hline $\begin{array}{l}\text { What consumers want } \\
\text { and how they use the } \\
\text { products (packaging, } \\
\text { meat cuts, varieties) }\end{array}$ & $\begin{array}{l}\text { F1, F2, } \\
\text { F3, F4, } \\
\text { F5 }\end{array}$ & $\begin{array}{l}\text { How vegetables look when they are } \\
\text { fresh } \\
\text { Be pickier about food, demand higher } \\
\text { quality } \\
\text { Take more interest in food and cooking }\end{array}$ & $\mathrm{C} 1, \mathrm{C} 3, \mathrm{C} 4, \mathrm{C} 8$ \\
\hline $\begin{array}{l}\text { What consumers think and care about. } \\
\text { What they like and dislike regarding } \\
\text { taste and quality }\end{array}$ & $\begin{array}{l}\mathrm{F} 1, \mathrm{~F} 2 \\
\mathrm{~F} 4, \mathrm{~F} 5\end{array}$ & $\begin{array}{l}\text { New, different, unusual (varieties of) } \\
\text { vegetables. How to use more } \\
\text { vegetables in cooking. }\end{array}$ & $\mathrm{C} 1, \mathrm{C} 4, \mathrm{C} 6, \mathrm{C} 8$ \\
\hline $\begin{array}{l}\text { That most consumers have little } \\
\text { knowledge about and do not care about } \\
\text { production methods }\end{array}$ & $\begin{array}{l}\text { F1, F2, } \\
\text { F5 }\end{array}$ & $\begin{array}{l}\text { How animals are raised and } \\
\text { slaughtered }\end{array}$ & $\mathrm{C} 7$ \\
\hline \multirow{2}{*}{$\begin{array}{l}\text { That consumers like to be recognized } \\
\text { by farmers }\end{array}$} & $\mathrm{F} 1$ & Trust the farmer & $\mathrm{C} 8$ \\
\hline & & $\begin{array}{l}\text { Where the farm is situated, what it } \\
\text { offers (activities, products) }\end{array}$ & $\mathrm{C} 3, \mathrm{C} 4, \mathrm{C} 5$ \\
\hline
\end{tabular}

at his stall. Through this strategy, conversations emerged about the products, cooking, and production methods and thus enabled learning within the instrumental domain. The beef producer (F4) did not let any customers slip away without talking about his production:

\section{C: How old was this one? / F4: The bull? / C: Yes. / F4: About two years. / C: Is that good? / F4: Yes, that's about the age they should be. You know, since it's organic, it takes a bit longer until they're ready. They only eat grass. [The customer selects a package.]}

The meat and cereal stalls were not as busy as the vegetable stalls, and thus the farmers had more opportunities to spend time talking with customers. The vegetable farmers had one or two helpers who sold and displayed produce. However, despite stress and waiting customers, F1 took time to talk to his customers:

\section{C: You have so many different varieties of potatoes; one doesn't know which to chose. I}

F1: We have many varieties of many things here. / C: But King Edward isn't available? /F1: No, that one needs too much poison. / $C$ : It doesn't yield so much either, does it?

/F1: We only grow organic here.

At the stall of the second vegetable farmer (F2), customers were more numerous, lines were longer, and the speed of transactions was faster. This farmer used the helpers for selling and spent most of his time taking out more produce. Thus, he was less confronted with customers, and the helpers did not take the initiative for conversations with customers.

The content (i.e., the information about factual matters) of the communications that took place at the farmers' markets offered opportunities for customers and farmers to learn within the instrumental domain. Customers had the possibility to learn about, for example, what to ask for; when, why, and from whom; and how to use new produce offered by the local farmers. Farmers had the possibilities to learn what their customers knew about local food production, what they wanted, and how to meet their wishes and demands. Thus, 
Table 5. Observed conversations at the farmers' stalls at the market.

\begin{tabular}{lccccccc}
\hline \hline Farmer & $\begin{array}{c}\text { Number of } \\
\text { documented } \\
\text { conversations }\end{array}$ & $\begin{array}{c}\text { How to use } \\
\text { products }\end{array}$ & $\begin{array}{c}\text { About the } \\
\text { products }\end{array}$ & $\begin{array}{c}\text { Production } \\
\text { methods of the } \\
\text { farm }\end{array}$ & $\begin{array}{c}\text { Give } \\
\text { feedback, } \\
\text { confirm } \\
\text { relation }\end{array}$ & $\begin{array}{c}\text { Farm } \\
\text { location }\end{array}$ & $\begin{array}{c}\text { Market } \\
\text { practicalities }\end{array}$ \\
\hline F1 & 55 & 8 & 19 & 14 & 16 & 0 & 6 \\
F2 & 19 & 2 & 12 & 2 & 4 & 0 & 0 \\
F3 & 28 & 12 & 4 & 2 & 8 & 2 & 4 \\
F4 & 29 & 6 & 9 & 3 & 11 & 1 & 4 \\
F5 & 22 & 4 & 6 & 2 & 6 & 2 & 3 \\
Total & 153 & 32 & 50 & 23 & 45 & 5 & 17 \\
\hline
\end{tabular}

customers and farmers could adapt to each other through the feedback they gave each other. This adaptive capacity was expressed, for example, through customers claiming that they ate more vegetables or had become more quality conscious. Adaptive farmers secured their market position by offering the diversity of produce demanded by customers or by offering information to customers.

\section{Communicative learning at the farmers' markets}

Although the results of communicative learning as defined above can be used in an instrumental way (for instance, by trying to influence other actors), the purpose of communicative learning is not in itself instrumental, it is to improve communication and refers to human beings as social, situational, and relational.

At the same time, learning within the communicative domain is tightly linked to, and supportive of, learning within the instrumental domain and vice versa. An utterance is always communicative because it shapes a meaning about what is said for the one who is listening. Thus, the more a customer knows about the perspective of a farmer, the more meaningful and relevant the information about factual matters that the farmer may give to the customer. This, of course, also holds for a farmer listening to a customer.

A common kind of conversation observed on market occasions between farmers and customers was of the kind: "Some carrots, please" or: "Anything else? Thirty crowns ${ }^{[1]}$, please" (Table 5). Even though they may seem very simple, these exchanges can be regarded as a basis for communicative learning, since a prerequisite for learning within this domain is opportunities to meet face-to-face and communicate. This is why every interaction at the market has to be considered a potential communicative learning opportunity (Table 6). However, the interactions between customers and producers at the farmers' market did not take place in a social vacuum. Instead, the farmers' market can be seen as a place where both sets of actors created and recreated norms and values related to food production and consumption.

Farmers and customers shared values on a number of issues. In the interviews, customers declared that they appreciated the availability of high-quality, environmentally friendly, and ethical products, as well as the possibility to support local producers (Table 7). Farmers emphasized the appreciation and feedback they got from their customers and were proud of being able to offer the products the customers wanted. In addition, two farmers valued 
Table 6. Observed learning potential at the farmers' market.

\begin{tabular}{llcllll}
\hline \hline Farmer & $\begin{array}{l}\text { Observations } \\
\text { (minutes/number } \\
\text { of occasions) }\end{array}$ & $\begin{array}{l}\text { Number of } \\
\text { documented } \\
\text { observations }\end{array}$ & $\begin{array}{l}\text { Estimated } \\
\text { portion of } \\
\text { conversations } \\
\text { containing more } \\
\text { than transactions } \\
(\%)^{\dagger}\end{array}$ & $\begin{array}{l}\text { Number of } \\
\text { documented } \\
\text { observations } \\
\text { with potential } \\
\text { for instrumental } \\
\text { learning }\end{array}$ & $\begin{array}{l}\text { Potential for } \\
\text { instrumental } \\
\text { learning from } \\
\text { estimated total } \\
(\%)\end{array}$ & $\begin{array}{l}\text { Potential for } \\
\text { communicative and } \\
\text { emancipatory } \\
\text { learning }(\%)\end{array}$ \\
\hline F1 & $135 / 3$ & 55 & $60-80$ & 39 & 50 & 100 \\
F2 & $95 / 4$ & 19 & $10-30$ & 15 & 16 & 100 \\
F3 & $80 / 2$ & 28 & $80-100$ & 20 & 65 & 100 \\
F4 & $135 / 2$ & 28 & $90-100$ & 18 & 61 & 100 \\
F5 & $130 / 2$ & 22 & $90-100$ & 16 & 70 & 100 \\
\hline
\end{tabular}

${ }^{\dagger}$ Estimations based on observations of the numbers of transactions that contained conversation (exact number not available because the markets were very busy).

their ability to track their products from farm to consumer, which they regarded as satisfying and as giving meaning to work on the farm (Table 7).

Unintentionally, through every single transaction, farmers and customers learned about norms and values related to the market. They learned, for instance, what was regarded as "good food" (locally produced, organic, fresh, etc.), "good customers" (customers who care about quality, support local organic farmers, etc.), and "good farmers" (farmers who provide local and fresh food to their customers). They also learned how to act and communicate in order to fulfill the expectations of what was "good" in this context.

Building trust and establishing relations with other actors is important for learning within the communicative domain (Mezirow 1991). Though few of the interviewees included these aspects in their explanations about what they learned by attending the farmers' market, they all mentioned the opportunities for face-to-face interaction - the fundamental way of establishing relations, building trust, and thus communicating in a meaningful way - as an important motive for attending the market (Table 7). Aside from being able to get a higher price per kilogram produce at the market compared with other market channels, all farmers emphasized the possibility to meet customers faceto-face as a crucial reason for selling at a farmers' market (Table 7). One farmer (F2) described his feeling of contact with customers in this way:

The added value or what you want to call $i t$, it is that it is so tangible ... I almost know who will eat what I grow. It is a strong force in this. Even if all [consumers] do not say anything, they do shop, and if they shop they like it.

Customers reported that meeting the producers not only enhanced their shopping experience but also increased their trust in the farmers and thus in the produce sold at the market. One customer (C3) had this to say:

The advantage is that I have the person that cultivated, that person is proud of his products, wants to sell the best and thatfeels good ... I think it is satisfying to know who has produced and I think up there [at the market] standing eye to eye with the person who did it and that feels good. 
Table 7. Reasons why farmers and customers attended the farmers' market.

\begin{tabular}{llll}
\hline \hline Reasons for selling at the market & $\begin{array}{l}\text { Farmers stating this } \\
(n=5)\end{array}$ & $\begin{array}{l}\text { Reasons for shopping at the } \\
\text { market }\end{array}$ & $\begin{array}{l}\text { Consumers stating this } \\
(n=9)\end{array}$ \\
\hline Meeting consumers face-to-face & F1, F2, F3, F4, F5 & Meet producers face-to-face & C1, C3, C6, C7, C8, C9 \\
Social event & F5 & Nice atmosphere, fun & C1, C3, C5, C6, C7 \\
Offer fresh produce of high quality & F1, F2, F4 & $\begin{array}{l}\text { Fresh, high-quality, tasty, } \\
\text { safe, genuine products }\end{array}$ & C2, C3, C4, C5, C6, C7, C8, \\
Get feedback from consumers & F1, F2, F3, F4, F5 & $\begin{array}{l}\text { Trust farmers more than } \\
\text { supermarkets }\end{array}$ & C3, C8 \\
Better price per kilogram produce & F1, F2, F3 & $\begin{array}{l}\text { Want to support local/ } \\
\text { small-scale producers }\end{array}$ & C3, C5, C6, C7, C8, C9 \\
$\begin{array}{l}\text { Better control of the whole } \\
\text { production chain }\end{array}$ & F2, F3 & $\begin{array}{l}\text { Want local/Swedish } \\
\text { produce }\end{array}$ & C3, C5, C6, C7, C9 \\
$\begin{array}{l}\text { Contribute to sustainable } \\
\text { consumption }\end{array}$ & F4 & $\begin{array}{l}\text { For the environment/animal } \\
\text { welfare }\end{array}$ & C2, C5, C6, C7, C8 \\
\hline
\end{tabular}

The face-to-face interaction that took place at the farmers' market improved the opportunities for learning to build trust and develop tight relationships among farmers and customers. This is important because it can increase the actors' interest in each other and improve the possibilities to understand more about the perspectives, norms, and values of each other and thus communicate in a relevant and meaningful way. Trust is also important because it supports the opportunities for consumers and producers to manifest and strengthen shared norms and values.

\section{Emancipatory learning at the farmers' markets}

It was difficult to find indications of emancipatory learning compared with instrumental and communicative learning in the empirical data in the study. However, because emancipatory learning is a function of both communicative and instrumental learning, there were opportunities in all interactions for customers and farmers attending the market to learn about themselves and their respective roles (Table 6). These opportunities could have strengthened and developed their roles and their identities as actors in this alternative food market, which can be seen as opportunities of learning about themselves. This conversation between two customers was observed on one of the market occasions:

Woman 1: These look nice. Did you try this one [a tomato variety]? / Woman 2: Yes, I bought it last week, it has a thinner skin, more sour. / Woman 1: A bit like this one [showing another variety]? / Woman 2: Yes, it is apparantly an older variety. / Woman 1: You mean it was grown earlier? / Woman 2: Yes, these older tomatoes have thinner skin ... these are different varieties, these are much tastier.

However, although customers and farmers have the potential to develop their expertise as local food actors at the farmers' markets, there is no evidence that this leads to self-reflection or develops their understanding of themselves. For such a claim, longer and more in-depth studies would be necessary. 


\section{DISCUSSION}

By attending the farmers' markets, the customers in this study increased their opportunities for learning (cf. Hinrichs et al. 2004). As in other studies, the farmers in our study used environmentally friendly production methods, most farms were small in size, the farmers liked to socialize and get feedback from customers, and they found the market to be an appropriate market channel for them (cf. Marsden et al. 2000, Brown 2002, Griffin and Frongillo 2003, Kirwan 2006, Smithers et al. 2008). As reported elsewhere, the customers in this study were looking for fresh, high-quality, local food; they liked the atmosphere at the market; and they were able to gain additional knowledge about food production (cf. Brown 2002, Sage 2003, Lamine 2005, Kirwan 2006, Moore 2006, Connell et al. 2008). Although some customers in the study found it valuable to be able to ask questions about products and production methods, the farmers did not perceive that customers asked questions frequently. This was confirmed by our observations and another study (Åsebø et al. 2007), in which farmers found it important to volunteer information about varieties and production methods, whereas customers considered this less important. The customers in this study had an image of themselves being qualityconscious and caring for the environment, animals, and local farmers. Their values for food seem to correspond to what Connell et al. (2008) called "good food." In addition, the market was a way to obtain "good food" and to express values about food.

Like many customers in other studies of farmers' markets, those in this study had some kind of higher or professional education (cf. Hunt 2007). Furthermore, the two markets in this study did not specifically aim to attract low-income or minority consumers. On the contrary, the Stockholm market was situated in an "alternative" area with a high density of high-income and quality-conscious consumers. The Örebro market was situated in a mixed area, but still in the city, whereas low-income people in Sweden typically live in the suburbs. Although Sweden is a less stratified society than, for example, the United Kingdom or the United States, this still raises questions of access to local food (cf. Guthman 2008, Macias 2008).

This study explored learning as the process of using prior interpretation to construe a new or revised interpretation of the meaning of one's experience in order to guide further action (Mezirow 1991).
Through observations at the market and through interviews with farmers and customers, we were able to examine and describe instrumental and communicative learning. Information on factual matters exchanged during face-to-face interactions such as information about prices, supply, and demand of different produce, and production and consumption conditions for farmers and customers were attributed to the instrumental learning domain. Learning within the communicative domain is enabled by the norms, values, and interests expressed by those involved in the interaction. Farmers and customers in this study were able to develop trust in each other and acknowledge that they shared norms and values with other actors at the market. This could increase their interest in learning (cf. Kegan 2000). It seems that local food networks have the potential to promote and develop informed consumers by nurturing the ethics of ecological citizenship and providing a means for their expression (Seyfang 2006). Overall, we found evidence of what a consumer study by Svenfelt and Carlsson-Kanyama (2010) termed local ecological knowledge (knowledge about what can be grown locally during different seasons, what can be grown in the area, how the weather affects production, etc.) and indirect ecological knowledge (e.g., knowledge about how to store and prepare products). However, neither observations nor interviews gave any direct indications of emancipatory learning. Participating in the local food system might not have enabled actors to learn about themselves in the selfreflective way emphasized by Mezirow (1991). On the other hand, participating seems to have developed customers' competence as local consumers and farmers' competence as local producers, thus making their choices and actions more reflective and informed.

As farmers and customers met, communicated, and gave feedback to each other, they seemed to have the opportunity to learn, that is, to construe new or revised interpretations of their experiences that could change their attitudes and guide their decision making and behavior, or other actions related to food consumption and production. Such learning may lead to better comprehension of the complexity and context of the food system and the actors involved. For example, when farmers volunteered information about production methods or introduced "new" vegetables to customers, the latter learned about the availability of produce at different times of the year, thus improving their understanding of food production and allowing them to adjust their 
demand for different food items. As a result, customers could have been inspired to eat a more seasonal diet, which in turn could decrease transportation and energy inputs in cultivation and thus lower the environmental load (CarlssonKanyama 2004; Svenfelt and Carlsson-Kanyama 2010). Customers also learned to expand their repertoire as local consumers: They learned about what to ask for, when and from whom, and how they could use and cook local produce. In turn, farmers learned what the customers wanted, what they knew about local food production, and what they thought about the products offered at the market. Thus, the farmers were able to adjust their products to fit customers better and provide information about production.

The learning and trust that developed between consumers and producers at the markets seemed to have contributed to the adaptive capacity of the actors (cf. Walker et al. 2006). Consumers and producers had the opportunity to adapt to each other and to change their behavior in the direction of a more robust food system. For example, the farms in this study had high on-farm biodiversity, partly due to the face-to-face interactions at the markets (Björklund et al. 2009). Customers were confident that they were getting the high-quality products they demanded, and farmers knew that customers were more loyal if they built social relationships as well as market relationships with them. These closed feedback loops can be seen as a prerequisite for sustainable development (Levin 1999, Folke et al. 2002, Sundkvist et al. 2005). Because learning and adaptation are defining characteristics of resilience (Carpenter et al. 2001), we suggest that learning customers and farmers contribute to a more resilient food system.

It is important to note, however, that farmers and customers did not make use of all the potential learning inherent in face-to-face interactions; for example, most customers did not ask specific questions (cf. Svenfelt and Carlsson-Kanyama 2010). However, the institution of the market established a baseline of trust for them (cf. Holloway and Kneafsey 2000, Kirwan 2006), where meeting and small talk was often enough to confirm the relationship and the shared values. The personal connection operated as an alternative expert system in which consumers used face-to-face interactions with producers rather than standard product certification (cf. Moore 2006). In addition, the relationship between increased knowledge, attitudes, and consecutive adjustment of behavior is complex (Gardner and Stern 1996, Stern 2000). Instrumental learning is not enough for people to change attitudes, and the "right" attitudes and values are not enough to make customers or farmers want to learn more. Likewise, the "right" knowledge or the "right" attitude is not enough to change behavior, for example, in the direction of a more resilient food system. Knowledge, attitudes, and behaviors need to develop side by side in order for changes in behaviors to be sustainable (Gardner and Stern 1996, Stern 2000). The farmers' markets described in this study seemed to have the potential to offer such an opportunity for farmers and customers. The actors had the possibility to express behaviors that were in accordance with their attitudes and values, while at the same time developing their knowledge on factual matters.

Despite the fact that close consumer-producer links foster customer loyalty, the farmers in this study were in a weak position due to their low turnover and high workload. However, we would argue that in an exceptional situation, such as a food scare, plummeting market prices, or failure of the mainstream food system in any other way, these farmers would be better off than those focusing on the national, retail-led food market. It can be argued that the farmers in this study have more adaptive capacity because the personal relationships enabled farmers to have a fairly secure income base through loyal customers, leaving them less dependent on standardized expert systems and large-scale food actors. Thus, "local partnerships" buffer vulnerability (cf. Lamine 2005).

\section{CONCLUSION}

Although learning is an important concept in the literature on resilience and local food systems, few authors have been able to describe the learning that takes place and what it could imply for sustainable development. We have attempted to show that the potential exists for instrumental, communicative, and possibly emancipatory learning through faceto-face interactions at farmers' markets. This, in turn, may enhance the adaptive capacity of the producers and consumers at farmers' markets. The adaptive capacity of those managing natural resources (such as agro-ecosystems) is a prerequisite for building resilience of these resources. When farmers and customers use interactions at farmers' markets to revise prior 
interpretations (or make new ones) about, for example, each other, food, and farming conditions, they gain a better understanding of the complexity of the food system and its context. This can influence consumer choices and farm management, and subsequently agro-ecosystems, in a sustainable direction. Thus, although local food systems such as farmers' markets are not the answer to all the problems in the mainstream food system, they do seem to work in an encouraging way.

Responses to this article can be read online at: http://www.ecologyandsociety.org/voll5/iss3/art29/ responses/

\section{Acknowledgments:}

The Swedish Research Council for Environment, Agricultural Sciences and Spatial Planning funded this research. The authors would like to thank participating farmers and consumers. We are also indebted to Asa Svenfelt, Lisa Deutsch, the Subject Editor, and two anonymous reviewers for useful comments on earlier drafts.

\section{LITERATURE CITED}

Adger, W. N. 2006. Vulnerability. Global Environmental Change 16:268-281.

Åsebø K., A. Moxnes Jervell, G. Lieblein, M. Svennerud, and C. Francis. 2007. Farmer and consumer attitudes at farmers markets in Norway. Journal of Sustainable Agriculture 30:67-93.

Alkon, A. H. 2008. From value to values: sustainable consumption at farmers markets. Agriculture and Human Values 25:487-498.

Allen, P. 2004. Together at the table: sustainability and sustenance in the American agrifood system. The Pennsylvania State University Press, University Park, Pennsylvania, USA.

Allen, P., M. FitzSimmons, M. Goodman, and K. Warner. 2003. Shifting plates in the agrifood landscape: the tectonics of alternative agrifood initiatives in California. Journal of Rural Studies 19:61-75.
Armitage, D., M. Marschke, and R. Plummer. 2008. Adaptive co-management and the paradox of learning. Global Environmental Change 18:86-98.

Berkes, F., J. Colding, and C. Folke, editors. 2003. Navitaging social-ecological systems. Building resilience for complexity and change. Cambridge University Press, Cambridge, UK.

Berkes, F., and C. Folke, editors. 1998. Linking social and ecological systems. Cambridge University Press, Cambridge, UK.

Björklund, J., L. Westberg, U. Geber, R. Milestad, and J. Ahnströ. 2009. Local selling as a driving force for increased on-farm biodiversity. Journal of Sustainable Agriculture 33:885-902.

Born, B., and M. Purcell. 2006. Avoiding the local trap: scale and food systems in planning research. Journal of Planning Education and Research 26:195-207.

Brown, A. 2002. Farmers' market research 1940-2000: an inventory and review. American Journal of Alternative Agriculture 17:167-176.

Bryman,A. 2004. Social research methods. Second edition. Oxford University Press, Oxford, UK.

Burke, K. 1966. Language as symbolic action: essays on life literature and method. University of California Press, Berkeley, California, USA.

Carlsson-Kanyama, A. 2004. Diet, energy and greenhouse gas emissions. Pages 809-816 in C. J. Cleveland, editor. Encyclopedia of energy. Elsevier, Philadelphia, Pennsylvania, USA.

Carpenter, S., B. Walker, J. M. Anderies, and M. Abel. 2001. From metaphor to measurement: resilience of what to what? Ecosystems 4:765-781.

Connell, D. J., J. Smithers, and A. Joseph. 2008. Farmers' markets and the "good food" value chain: a preliminary study. Local Environment 13:169-185.

Darnhofer, I., S. Bellon, B. Dedieu, and R. Milestad. 2010. Adaptiveness to enhance the sustainability of farming systems. A review. Agronomy for Sustainable Development, in press. 
DeLind, L. B. 2002. Place, work, and civic agriculture: common fields for cultivation. Agriculture and Human Values 19:217-224.

DuPuis, E. M., and D. Goodman. 2005. Should we go "home" to eat?: toward a reflexive politics of localism. Journal of Rural Studies 21:359-371.

Eden, S., C. Bear, and G. Walker. 2008. Mucky carrots and other proxies: problematising the knowledge-fix for sustainable and ethical consumption. Geoforum 39:1044-1057.

Edwards-Jones, G., L. M. i Canals, N. Hounsome, M. Truninger, G. Koerber, B. Hounsome, P. Cross, E. H. York, A. Hospido, K. Plassmann, I. M. Harris, R. T. Edwards, G. A. S. Day, A. D. Tomos, S. J. Cowell, and D. L. Jones. 2008. Testing the assertion that 'local food is best': the challenges of an evidence-based approach. Trends in Food Science and Technology 19:265-274.

Elmqvist, T., C. Folke, M. Nyströ, G. Peterson, J. Bengtsson, B. Walker, and J. Norberg. 2003. Response diversity, ecosystem change and resilience. Frontiers in Ecology and Environment 1:488-494.

Fazey, I., J. A. Fazey, J. Fischer, K. Sherren, J. Warren, R. F. Noss, and S. R. Dovers. 2007. Adaptive capacity and learning to learn as leverage for social-ecological resilience. Frontiers in Ecology and the Environment 5:375-380.

Feagan, R. 2007. The place of food: mapping out the "local" in local food systems. Progress in Human Geography 31:23-42.

Folke, C., S. Carpenter, T. Elmqvist, L. Gunderson, C. S. Holling, B. Walker, J. Bengtsson, F. Berkes, J. Colding, K. Danell, M. Falkenmark, L. Gordon, R. Kasperson, N. Kautsky, A. Kinzig, S. Levin, K.-G. Mäer, F. Moberg, L. Ohlsson, P. Olsson, E. Ostrom, W. Reid, J. Rockströ, H. Savenije, and U. Svedin. 2002. Resilience and sustainable development: building adaptive capacity in a world of transformations. Scientific Background Paper on Resilience for the process of The World Summit on Sustainable Development on behalf of The Environmental Advisory Council to the Swedish Government. [online] URL: http://www.sou.gov.se/ mvb/pdf/resiliens.pdf.
Folke, C., J. Colding, and F. Berkes. 2003. Synthesis: building resilience and adaptive capacity in social-ecological systems. Pages 352-387 in F. Berkes, J. Colding, and C. Folke, editors. Navigating social-ecological systems. Building resilience for complexity and change. Cambridge University Press, Cambridge, UK.

Forester, J. 1993. Critical theory, public policy and planning practice. State University of New York Press, Albany, New York, USA.

Gardner, G. T., and P. C. Stern. 1996. Environmental problems and human behavior. Allyn \& Bacon, Boston, Massachusetts, USA.

Griffin, M. R., and E. A. Frongillo. 2003. Experiences and perspectives of farmers from Upstate New York farmers' markets. Agriculture and Human Values 20:189-203.

Gunderson, L. H., S. R. Carpenter, C. Folke, P. Olsson, and G. Peterson. 2006. Water RATs (Resilience, Adaptability, and Transformability) in lake and wetland social-ecological systems. Ecology and Society 11(1):16. [online] URL: http:/ /www.ecologyandsociety.org/vol11/iss 1/art16/.

Gunderson, L. H., and C. S. Holling, editors. 2002. Panarchy. Understanding transformations in human and natural systems. Island Press, Washington, D.C., USA.

Guthman, J. 2008. "If they only knew": color blindness and universalism in California alternative food institutions. The Professional Geographer 60:387-397.

Guthman, J., A. W. Morris, and P. Allen. 2006. Squaring farm security and food security in two types of alternative food institutions. Rural Sociology 71:662-684.

Hendrickson, M. K., and W. D. Heffernan. 2002. Opening spaces through relocalisation: locating potential resistance in the weaknesses of the global food system. Sociologia Ruralis 42:347-369.

Hinrichs, C. C. 2000. Embeddedness and local food systems: notes on two types of direct agriculltural market. Journal of Rural Studies 16:295-303. 
Hinrichs, C. C. 2003. The practice and politics of food system localization. Journal of Rural Studies 19:33-45.

Hinrichs, C. C., G. W. Gillespie, and G. W. Feenstra. 2004. Social learning and innovation at retail farmers' markets. Rural Sociology 69:31-58.

Holloway, L., and M. Kneafsey. 2000. Reading the space of the farmers' market: a preliminary investigation from the UK. Sociologia Ruralis 40:285-299.

Hunt, A. R. 2007. Consumer interactions and influences on farmers' markets vendors. Renewable Agriculture and Food Systems 22:54-66.

Ilbery, B., D. Watts, S. Simpson, A. Gilg, and J. Little. 2006. Mapping local foods: evidence from two English regions. British Food Journal 108:213-225.

Jarosz, L. 2000. Understanding agri-food networks as social relations. Agriculture and Human Values 17:279-283.

Jarosz, L. 2008. The city in the country: growing alternative food networks in metropolitan areas. Journal of Rural Studies 24:231-244.

Kegan, R. 2000. In over our heads. The mental demands of modern life. Seventh edition. Harvard University Press, Cambridge, Massachusetts, USA.

Kirwan, J. 2006. The interpersonal world of direct marketing: examining conventions of quality at UK farmers' markets. Journal of Rural Studies 22:301-312.

Kvale, S. 1996. Interviews: an introduction to qualitative research interviewing. SAGE, Thousand Oaks, California, USA.

Lamine, C. 2005. Settling shared uncertainties: local partnerships between producers and consumers. Sociologia Ruralis 45:324-345.

LaTrobe, H. 2001. Farmers' markets: consuming local rural produce. International Journal of Consumer Studies 25:181-192.

Levin, S. 1999. Fragile dominion: complexity and the commons. Perseus, Reading, Massachusetts, USA.
Macias, T. 2008. Working toward a just, equitable, and local food system: the social impact of community-based agriculture. Social Science Quarterly 89:1086-1101.

Marsden, T., J. Banks, and G. Bristow. 2000. Food supply chain approaches: exploring their role in rural development. Sociologia Ruralis 40:424-438.

Mezirow, J. 1991. Transformative dimensions of adult learning. Jossey-Bass Publishers, San Francisco, California, USA.

Miles, M. B., and A. M. Huberman. 1994. Qualitative data analysis. An expanded sourcebook. Second edition. Sage Publications, London, UK.

Moore, O. 2006. Understanding postorganic fresh fruit and vegetable consumers at participatory farmers' markets in Ireland: reflexivity, trust and social movements. International Journal of Consumer Studies 30:416-426.

Olsson, P., C. Folke, V. Galaz, T. Hahn, and L. Schultz. 2007. Enhancing the fit through adaptive co-management: creating and maintaining bridging functions for matching scales in the Kristianstads Vattenrike Biosphere Reserve, Sweden. Ecology and Society 12(1):28. [online] URL: http://www.ec ologyandsociety.org/vol12/iss1/art28/

Pretty, J. 1998. The living land: agriculture, food and community regeneration in rural Europe. Earthscan, London, UK.

Sage, C. 2003. Social embeddedness and relations of regard: alternative "good food" networks in south-west Ireland. Journal or Rural Studies 19:47-60.

Seyfang, G. 2006. Ecological citizenship and sustainable consumption: examining local organic food networks. Journal of Rural Studies 22:383-395.

Smithers, J., J. Lamarche, and A. E. Joseph. 2008. Unpacking the terms of engagement with local food at the farmers' market: insights from Ontario. Journal of Rural Studies 24:337-350.

Stern, P. C. 2000. Toward a coherent theory of environmentally significant behavior. Journal of Social Issues 56:407-424. 
Sundkvist, ̊̊, R. Milestad, and A. M. Jansson. 2005. On the importance of tightening feedback loops for sustainable development of food systems. Food Policy 30:224-239.

Svenfelt, Å, and A. Carlsson-Kanyama. 2010. Farmers' markets: linking food consumption and the ecology of food production? Local Environment, in press.

Walker, B., L. Gunderson, A. Kinzig, C. Folke, S. Carpenter, and L. Schultz. 2006. A handful of heuristics and some propositions for understanding resilience in social-ecological systems. Ecology and Society 11(1):13. [online] URL: http://www.ecolog yandsociety.org/vol11/iss1/art13/.

Walker, B., C. S. Holling, S. Carpenter, and A. Kinzig. 2004. Resilience, adaptability and transformability in social-ecological systems. Ecology and Society 9(2):5. [online] URL: http://w ww.ecologyandsociety. org/vol9/iss2/art5/.

[1] "Crown" is the Swedish national currency (SEK). 